\title{
Inhibition of Long-Term Potentiation in the Dentate Gyrus of Freely Moving Rats by the Metabotropic Glutamate Receptor Antagonist MCPG
}

\author{
Gernot Riedel,' Giacomo Casabona, ${ }^{2 . a}$ and Klaus G. Reymann' \\ 'Department of Neurophysiology, Institute for Neurobiology, D-39008 Magdeburg, Germany, and Institute of \\ Pharmacology, University of Catania, School of Medicine, I-95125 Catania, Italy
}

Metabotropic glutamate receptors (mGluRs) are critically involved in the maintenance of long-term potentiation (LTP) (Reymann and Matthies, 1989; Behnisch et al., 1991; Izumi et al., 1991; Bashir et al., 1993). In order to assess further the physiological role of MGluRs in LTP, we injected freely moving rats with the recently available, competitive mGluR antagonist $(R, S)-\alpha$-methyl-4-carboxyphenylglycine (MCPG) intraventricularly and recorded extracellularly the population spike (PS) as well as the field excitatory postsynaptic potential (fEPSP) of the granule cells of the dentate gyrus in response to stimulation of fibers of the perforant path. MCPG was administered in two concentrations $(A=20 \mathrm{~mm} / 5 \mu \mathrm{l} ; B$ $=200 \mathrm{~mm} / 5 \mu \mathrm{l}$ ) either $30 \mathrm{~min}$ prior to or $5 \mathrm{~min}$ after LTP induction. Sodium chloride infusion served as a control. Normal synaptic transmission was not altered by MCPG. However, the mGluR antagonist inhibited LTP in a concentrationdependent manner. Concentration $A$ did not influence the potentiation shortly after the tetanus. In the PS, short-term potentiation (STP), which is decremental in its time course, occurred normally, but in contrast to controls the potentiation declined back to baseline values after 2-3 hr. This dose also reduced the posttetanic increase in the slope function of the fEPSP, and led to a time course of potentiation similar to that for the PS. Concentration B completely abolished the tetanus-induced potentiation. This block was similar to that obtained for the NMDA antagonist 2-amino-5-phosphonopentanoate (AP5). Both MCPG concentrations had no influence on the time course of preestablished LTP. These effects seem to be due to the action of the $(+)$-isomer of MCPG, since intracerebroventricular application of the (-)-isomer was without effect on the duration and magnitude of LTP.

In addition, we were interested in the mGluR subtypes involved in the blocking mechanism of MCPG. 1S,3R-aminocyclopentane-1,3-dicarboxic acid (ACPD)-activated PPI hydrolysis in hippocampal slices was competitively inhibited

\footnotetext{
Received Feb. 16, 1994; revised Mar. 31, 1994; accepted Apr. 21, 1994.

We are greatly indebted to Mrs. Silvia Vieweg for her helpfulness and skillful technical assistance, to Mr. R. Brown for improving the English style, and to Prof. F. Nicolctti for criticism on an earlier draft of the manuscript. This research was supported by a grant from the Federal Ministry for Science and Technology (BMFT, BEO 0316912 A) to K.G.R.

Correspondence should be addressed to Gernot Riedel, Ph.D., Department of Neurophysiology, Institute for Neurobiology, Brenneckestrasse 6, P.O. Box 1860, D-39008 Magdeburg, Germany.

Present address: Institut Alfred Fessard CNRS, Avenue de la terasse, 91198 Gif-sur Yvette, France.

Copyright $\odot 1995$ Society for Neuroscience $0270-6474 / 95 / 150087-12 \$ 05.00 / 0$
}

by MCPG at a concentration of $1 \mathrm{mM}$ or higher. In contrast, this concentration of MCPG did not affect the reduction of forskolin-stimulated CAMP formation by ACPD. These results corroborate recent findings that $m$ GluRs are required for the induction of LTP in CA1 and CA3 in vitro (Bashir et al., 1993; Sergueeva et al., 1993) and in vivo (Riedel and Reymann, 1993). The process of STP is found to be independent of mGluR activation. At very high concentrations MCPG may also block other glutamate receptors, for instance, the NMDA receptor, other mGluR subtypes, or it may act unspecifically. However, our biochemical data suggest that MCPG acts as an antagonist on mGluR subtypes linked to PPI hydrolysis (i.e., mGluR1 and mGluR5) in hippocampal LTP in vivo.

IKey words: hippocampus, long-term potentiation (LTP), metabotropic glutamate receptor (mGluR), dentate gyrus, in vivo, (R,S)- $\alpha$-methyl-4-carboxyphenylglycine (MCPG)]

Long-term potentiation (LTP) is a long-lasting enhancement of synaptic transmission evoked by brief high-frequency stimulation of synaptic pathways (Bliss and Lomo, 1973; Bliss and Lynch, 1988) or by pairing presynaptic activity with postsynaptic depolarization (Wigström and Gustafsson, 1986; Bindman et al., 1988). This form of activity-dependent synaptic plasticity is widely used as a model to investigate the cellular mechanisms of learning and memory. It is widely accepted that LTP consists of a superimposition of various processes, in which ionotropic receptors play a substantial role in both induction and maintenance of LTP at glutamatergic synapses. Furthermore, a number of intracellular enzyme-regulated cascades modulated by the activation of G-protein-coupled metabotropic glutamate receptors (mGluRs) have been identified as contributing to longlasting synaptic changes (Bliss and Collingridge, 1993; Reymann, 1993).

These mGluRs are either linked to the stimulation of phosphoinositide (PPI) hydrolysis (mGluR1 + mGluR5) or negatively coupled to adenylate cyclase activity (mGluR2-mGluR4, IIIGluR6 + mGluR7), as has been described recently (Sladeczek et al., 1985; Nicoletti et al., 1986; Sugiyama et al., 1987; Palmer et al. , 1989; Nakanishi, 1992; Tanabe et al., 1992). Some kinds of glutamate analogs, such as quisqualate, ibotenate, 1 -aminocyclopentane-1,3-dicarboxic acid (ACPD), (2S,1'S,2'S)-carboxycyclopropyl) glycine (L-CCG-I), and $\left(2 S, 1^{\prime} R, 2^{\prime} R, 3^{\prime} R\right)-2-(2,3-$ dicarboxycyclopropyl)glycine (DCG-IV), appear to be selective agonists for this glutamate receptor subtype in the mammalian CNS (Monaghan et al., 1989; Sugiyama et al., 1989; Ishida et 


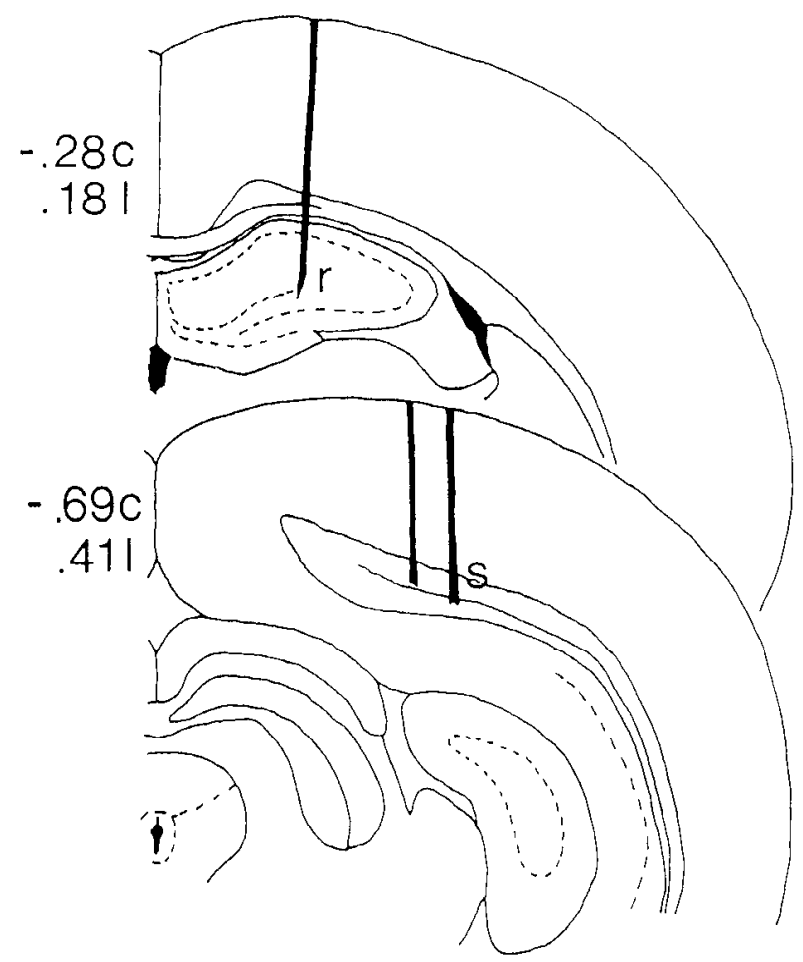

Figure 1. Schematic drawings of coronal sections through the rat brain showing the position of both recording and stimulation electrodes. The tip of the recording electrode $(r)$ was localized in the granular cell layer of the dentate gyrus for monitoring the population spike (PS) amplitude; the bipolar stimulation sites $(s)$ were located in the perforant path fibers. Numbers represent stereotaxic coordinates relative to bregma ( $c$, caudal; $l$, lateral)

al., 1990, 1993a,b; Nakagawa et al., 1990; Schoepp et al., 1990a; Porter et al., 1992; Shinozaki and Ishida, 1992). At present there is only preliminary evidence that activation of mGluRs also activates protein kinase $\mathrm{C}(\mathrm{PKC})$, which enables the late phases of LTP (Lovinger et al., 1987; Reymann et al., 1988). Dircct evidence for a link of $\mathrm{mGluR}$ to the activation of PKC exists only for cultured striatal neurons (Manzoni et al., 1990).

Few mGluR antagonists have been investigated in their capacity to prevent LTP in the hippocampus of rodents. Initial experiments using the nonspecific mGluR antagonist 2-amino4-phosphonobutyrate (AP4) selectively inhibited the maintenance of LTP in a manner similar to that found after block of PKC (Reymann et al., 1988; Reymann and Matthies, 1989; Colley et al., 1990). Similar results were obtained with the more selective antagonist 2-amino-3-phosphonopropionate (AP3) (Behnisch et al., 1991; Izumi et al., 1991; Behnisch and Reymann, 1993). In support of these antagonist studies, application of the selective mGluR agonist ACPD (Palmer et al., 1989. Desai and Conn, 1991) increases the amplitude of LTP (McGuiness et al., 1991a,b; Behnisch and Reymann, 1993), and may enable STP-inducing high-frequency trains to elicit LTP (Aniksztejn et al., 1992). Even an induction of a late and stable form of LTP without the short-term component (Bortolotto and Collingridge, 1992, 1993) by application of ACPD in the absence of a tetanus was described, although the appropriate conditions for this phenomenon are not yet fully understood (Behnisch and Reymann, 1993).

Most recently, investigations with the selective and competitive $\mathrm{mGluR}$ antagonist $(R S)$ - $\alpha$-methyl-4-carboxyphenylglycine
(MCPG) (Eaton et al., 1993) have proved that the coactivation of NMDA receptors and mGluRs is required to elicit a stable and long-lasting LTP in CA1 and CA 3 neurons in vitro (Bashir et al., 1993; Sergueeva et al., 1993). In addition, we provided preliminary evidence that MCPG was also able to block LTP in dentate gyrus neurons (Riedel and Reymann, 1993).

To characterize further the function of mGluRs in the mechanisms of LTP, we addressed the following questions using MCPG. (1) Is the activation of mGluRs during brief high-frequency shocks required to clicit LTP in the dentate gyrus in vivo or is it possible to inhibit preestablished LTP by posttetanic application of MCPG? (2) Does MCPG inhibit different phases of LTP in a concentration-dependent manner? (3) Which mGluR subtypes are involved in the block of LTP in response to drug treatment?

We here provide compelling evidence that $\mathrm{MCPG}$, depending on the concentration, blocks different phases of potentiation in the dentate gyrus in vivo. Low doses selectively block LTP, whereas higher concentrations are found to inhibit the tetanusinduced STP as well. Moreover, these effects are related to the selective block of mGluR1 and mGluR5, since MCPG was found to block PPI hydrolysis selectively, leaving inhibition of cAMP formation intact.

\section{Materials and Methods}

Animals. One hundred and forty-six male Wistar rats, weighing 300 $400 \mathrm{gm}$, were examined. After chronic implantation, animals were housed individually with free access to water and food pellets under a $12 / 12$ $\mathrm{hr}$ day/night cycle. For measurements we transferred the rats into special test cages $(40 \times 40 \times 50 \mathrm{~cm})$ with an equilibration period of $12-15 \mathrm{hr}$. Water and food were available ad libitum

Chronic preparation of electrodes and cannulas. For the chronic implantation of the electrodes, rats were anesthetized with pentobarbitone $(40 \mathrm{mg} / \mathrm{kg}$, i.p.) and mounted in a stereotaxic framc. The skin was removed and selective holes were drilled into the skull for the specific implantation of electrodes and cannulas relative to bregma. A bipolar stimulation electrode was placed in the perforant path (c, $-0.69 ; 1,0.41)$ and a monopolar recording electrode was lowered into the granule cell layer of the dentate gyrus of the right hemisphere (c, $-0.28 ; 1,0.18$; Fig. 1).

The depth of the electrodes was adjusted such that the population spike (PS) amplitude (difference between the first positive and negative deflection) was maximal. The laminar profile of the evoked potentials was used as a guide to determine the appropriate depth. Two stainless steel screws, which served as reference electrode and electrical ground, were fixed on the contralateral skull above the frontal and parietal cortex, respectively. The free ends of the electrodes were inserted into a rubber socket and cemented to the head with dental acrylic. In addition, a cannula was implanted into the lateral ventricle of the right hemisphere for drug application. Rats were allowed 5-7 d in their home cages to recover from surgery.

Measurements in freely moving animals. At the beginning of the test session the implanted electrodes were connected to flexible cables. The recorded signals from the microelectrodes were led through a swivel commutator, amplified using a differential amplifier (band pass $0.1 \mathrm{~Hz}$ to $10 \mathrm{kHz}$ ), and transformed via an A/D interface (CED 1401, Cambridge Electronic Design) to store data on a PC disk.

At the beginning of each experiment, input-output curves were determined to assess the maximum of the PS amplitudes or the fEPSP slope functions (see Fig. 2 for detailed description of field recordings). Five test stimuli (biphasic pulses, $0.1 \mathrm{msec}$ half-wave duration, interpulse interval of $4 \mathrm{sec}$ ) were applied with varying stimulation strength and averaged subsequently. Prior to tetanic stimulation, a baseline was recorded for $30 \mathrm{~min}$, during which the test stimulus intensity was set a lcvel that evoked a PS amplitude of $40 \%$ of the maximum. Brief tetanic stimulation ( 10 bursts of 15 stimuli, $200 \mathrm{~Hz}, 0.2 \mathrm{msec}$ duration, interburst interval of $10 \mathrm{sec}$ ) was administered at test stimulus current through the same stimulation electrode. To avoid behavioral influences on the evoked potentials, tetanic stimulation was applied only when rats were 
at rest (Buszaki et al., 1981; Hargreaves et al., 1990). Posttetanic recordings lasted up to $24 \mathrm{hr}$.

All animals were tested twice with an interval of 1 week. In one test session, the vehicle was injected, whereas in the other one MCPG was applied. The sequence of measurements was randomized to avoid serial effects. At the end of the experiment animals were decapitated and the brains were removed for histological verification of the position of electrodes and cannulas (Fig. 1).

Drugs and drug application. Two stock solutions of (RS)- $\alpha$-methyl4-carboxyphenylglycine (MCPG) (Tocris Neuramin, Bristol, UK) were dissolved in equimolar $\mathrm{NaOH}(1 \mathrm{M}$; Sigma, St. Louis, MO) and small aliquots were stored at $-20^{\circ} \mathrm{C}$. Solution A contained $0.208 \mathrm{mg}$ of MCPG $(20 \mathrm{~mm} / 5 \mu \mathrm{l})$, and solution $\mathrm{B}, 2.08 \mathrm{mg}(200 \mathrm{~mm} / 5 \mu \mathrm{l})$, per aliquot, respectively. Before use the drug was further diluted 50 -fold by adding saline ( $0.9 \%$ sodium chloride; Fluka, Buchs, Switzerland). Sodium chloride (vehicle) served for control application. Both solutions had a $\mathrm{pH}$ of 7.0. MCPG and the vehicle were injected intracerebroventricularly by means of a microsyringe (injection time, $5 \mathrm{~min}$ ) at a volume of $5 \mu \mathrm{l}$ either $30 \mathrm{~min}$ prior to or $5 \mathrm{~min}$ following tetanic stimulation. An effective concentration of MCPG at brain levels was assessed to be approximately $50 \mu \mathrm{M}$ (concentration A) or approximately $500 \mu \mathrm{M}$ (concentration $B$ ), if one assumes an equal distribution and the brain volume to be $2 \mathrm{ml}$. If applied pretetanically, baseline measurements continued for $0.5 \mathrm{hr}$, recording at $5 \mathrm{~min}$ intervals. This ensured that the mGluR antagonist had no influence on normal transmission. To corroborate this finding further, a group of animals received MCPG without a following tetanization.

To determine the duration of the efficacy of MCPG to block mGluRs, a group of rats was tested in their capacity to express LTP $24 \mathrm{hr}$ after drug application. Additionally, we tested whether posttetanic application 5 min after tetanic stimulation influences the time course of preestablished LTP. To differentiate the effects of the $(+)$ - and the $(-)$ isomer of MCPG we also injected the (-)-MCPG (Tocris Neuramin) in a series of animals. The preparation of the solutions was identical to that described for the racemate. Only one concentration (1.04 mg per aliquot) was tested.

The results of intracerebroventricular injection of the mGluR antagonist were compared to the effect of NMDA receptor antagonists. Therefore, 2-amino-5-phosphonopentanoic acid (AP5; Tocris Neuramin, Bristol, UK) was dissolved in sodium chloride $(0.9 \%)$ prior to application. AP5 $(0.024 \mathrm{mg})$ was injected intracerebroventricularly by means of a microsyringe (injection time, $5 \mathrm{~min}$ ) at a volume of $5 \mu 130 \mathrm{~min}$ prior to telanic stimulation. Thereafter, the effective concentration of AP5 at brain levels was assessed to be approximately $50 \mu \mathrm{M}$.

Measurement of PPI hydrolysis in brain slices. Inositol phospholipid hydrolysis was determined by measuring the accumulation of ${ }^{3} \mathrm{H}$-inositol monophosphate $\left({ }^{3} \mathrm{H}\right.$-InsP) in the presence of $\mathrm{Li}^{+}$, as described previously by Nicoletti et al. (1986). In brief, hippocampal slices were preincubated with $3 \mu \mathrm{Ci} / \mathrm{ml}$ of myo- $2-{ }^{3} \mathrm{H}$-inositol (specific activity, 16.5 $\mathrm{Ci} / \mathrm{mmol}$ ) for $24 \mathrm{hr}$, rinsed extensively with prewarmed Krebs-Henseleit buffer (equilibrated with $95 \% \mathrm{O}_{2} / 5 \% \mathrm{CO}_{2}$ to $\mathrm{pH} 7.4$ ), and then stimulated with trans-ACPD in the presence of $10 \mathrm{~mm} \mathrm{Li}^{+}$at $37^{\circ} \mathrm{C}$ for 30 min, whereas MCPG, when present, was added 1 min prior to ACPD application.

The reaction (release of ${ }^{3} \mathrm{H}$-inositol phosphates from membrane phospholipids) was terminated by addition of ice-cold methanol/water (1: 1). After further addition of chloroform and water, phases were separated, and the ${ }^{3} \mathrm{H}$-InsP present in the aqueous phase was separated by anion exchange chromatography and quantified according to Berridge et al. (1982).

All chemicals except MCPG and $1 S, 3 R$-ACPD were purchased from Sigma (St. Louis, MO).

Measurement of $C A M P$ formation in brain slices. Formation of cAMP was determined by quantitative assignment of forskolin-stimulated cAMP using a radioimmunoassay (Casabona et al., 1992; Gennazzani et al., 1993). Hippocampal slices were incubated for 35-45 $\mathrm{min}$ in KrebsHenseleit buffer (equilibrated with $95 \% \mathrm{O}_{2} / 5 \% \mathrm{CO}_{2}$ to $\mathrm{pH} 7.4$ ). Small $40 \mu \mathrm{l}$ aliquots of gravity-packed slices, previously transferred into polyethylene tubes, were incubated 20 min prior to drug treatment. mGluR agonists were added $2 \mathrm{~min}$ before forskolin. MCPG, when present, was added $15 \mathrm{~min}$ prior to ACPD. Another incubation of $15 \mathrm{~min}$ followed. Addition of ice-cold $0.8 \mathrm{M} \mathrm{HClO}_{4}$ (final volume, $\mathrm{I} \mathrm{ml}$ ) terminated the reaction. Samples were then sonicated for $10-15 \mathrm{sec}$ (Branson Sonifier B-12 at maximal intensity) and stored at $4^{\circ} \mathrm{C}$. Before centrifugation at low speed on the next day, we added the samples to $110 \mu \mathrm{l}$ of $2 \mathrm{M} \mathrm{K}_{2} \mathrm{CO}_{3}$.
The supernatant was diluted in water $(1: 10)$ and used for quantitative determination of the cAMP content by radioimmunoassay (commercially available NEC 033, New England Nuclear-Dupont). Parallel samples were solubilized with $0.5 \mathrm{M} \mathrm{NaOH}$ for assessment of the protein content, as described by Lowry et al. (1951). The protein concentration was found to be highly stable in various samples within the same experiment.

All chemicals except MCPG and $1 S, 3 R$-ACPD were purchased from Sigma (St. Louis, MO).

Statistical analysis. Comparison between groups was calculated statistically by means of the Mann-Whitney $U$ test $(P<0.05)$.

\section{Results}

\section{$M C P G$ and normal transmission}

In the first series of experiments we investigated the effect of MCPG on normal synaptic transmission in vivo. Test animals received $5 \mu \mathrm{l}$ of the drug intracerebroventricularly and were monitored for $24 \mathrm{hr}$ after applying test stimuli, which elicited $40 \%$ of the maximal PS amplitude before treatment. As shown in Figure 2, we found no concentration-dependent change in baseline recordings during $24 \mathrm{hr}$. The PS amplitude remained stable at levels of $100 \%$. Therefore, it seems unlikely that MCPG directly influences the excitability of postsynaptic neurons or presynaptic transmitter release under normal conditions in the investigated pathway.

\section{Vehicle application and duration of LTP}

To assess further the possible influences of the solvent in which MCPG was diluted prior to application, we injected rats with a vehicle solution of $\mathrm{NaCl}$. Figure 3 summarizes the results. It clearly indicates that the vehicle does not alter normal transmission in its magnitude and duration during baseline recordings as well as tetanus-induced LTP. We found an increase in PS amplitude, due to the high-frequency trains, up to $250 \%$, which slowly declines to $180 \% 24 \mathrm{hr}$ posttetanus. Posttetanically, the PS amplitude, measured as the difference between the first positive and negative deflection, increases up to $250-300 \%$. This enhancement persists for $24 \mathrm{hr}$.

These results ensure that the vehicle has no influence on the induction and maintenance of LTP, and further suggest that alterations that may occur under MCPG treatment are directly linked to the effects of the drug.

While recording from the somatic layer of the granule cells in the dentate gyrus, we also recorded the population IEPSP as the maximum slope between the baseline potential and the peak of the first positive wave (Fig. $4 \mathrm{C}$ ). We found a significant increase in the population $\mathrm{EEPSP}$ slope function of $20 \%$, which also lasted up to $24 \mathrm{hr}$.

\section{Effects of $M C P G$ on $L T P$}

Drug application $30 \mathrm{~min}$ prior to tetanization also does not alter the PS amplitude evoked by test stimuli during baseline measurement (Fig. 4). Brief tetanic stimulation induced a pronounced potentiation up to $250-300 \%$ only in group $\mathrm{A}$, where the low concentration of MCPG was applied. This potentiation declined back to baseline levels in $2-3 \mathrm{hr}$ and no recovery occurred within $24 \mathrm{hr}$. This decremental phase, defined as shortterm potentiation (STP) (Malenka, 1991; Bliss and Collingridge, 1993), lasted for 2-3 hr, after which the PS amplitude was back at baseline levels. The recorded PS amplitude then remained stable at baseline levels. The amplitude of the posttetanic potentiation was in a range comparable to the one found in vehicle- 

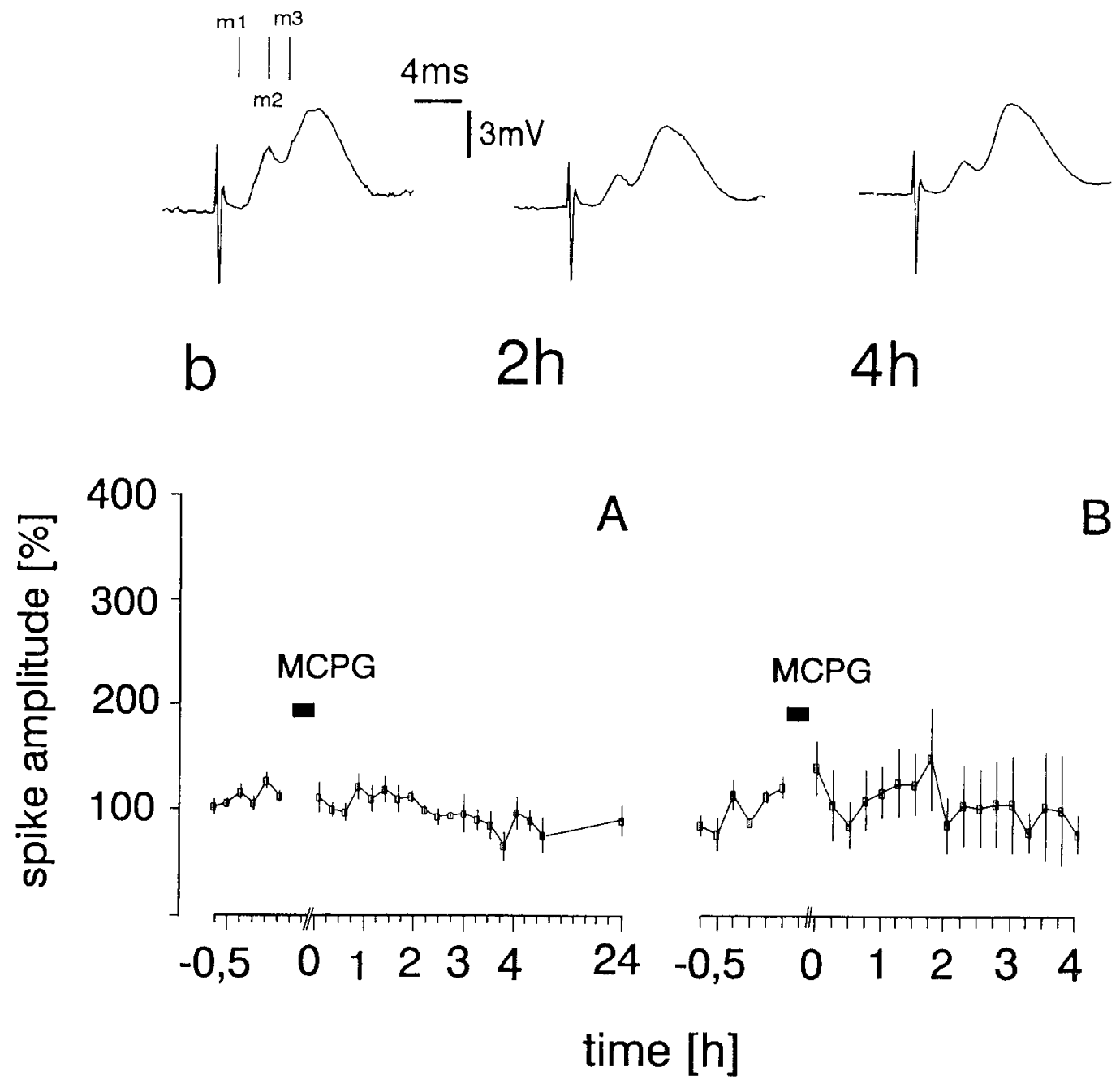

Figure 2. Effects of $(R, S)$ - $\alpha$-mcthyl-4-carboxyphenylglycine (MCPG) on normal synaptic transmission. The graphs summarize the data of the low concentration (20 mM MCPG/5 $\mu \mathrm{l}, n=7 ; A)$ and the high concentration (200 mM MCPG, $n=6 ; B$ ) plotted as average percentage change from baseline responses. Error bars indicate SEM; the horizontal bar marks the time of intraventricular MCPG application. Neither concentration alters the PS amplitude in response to test stimuli measured for 4-24 hr. Above are shown representative averages of five traces, respectively, recorded at baseline $(b)$ conditions as well as 2 and $4 \mathrm{hr}$ postdrug. It is clearly evident that no change in PS occurs after MCPG application. In the first trace (b) the markers $(m 1, m 2, m 3)$ were inserted to demonstrate the points of measurement of the fEPSP slope and PS amplitude. The steepness of the first positive deflection between $m 1$ and $m 2$ was used to measure the slope function of the fEPSP, whereas the difference between the first positive $(\mathrm{m} 2)$ and negative $(\mathrm{m} 3)$ deflection was calculated as PS amplitude. This mode of measurement was also applied for all other traces shown in subsequent figures.

treated rats (Fig. 3). A statistically significant difference exists between the MCPG-treated and the vehicle-treated group after $2.5 \mathrm{hr}\left({ }^{*}\right.$ in Fig. $\left.4 A ; p<0.05\right)$. Original traces recorded at different time points during the experiment support this observation (Fig. 4E).

With reference to this effect, it is of particular interest to concentrate on changes of the slope function of the population fEPSP due to MCPG injection. Figure $4 D$ summarizes the results for the low MCPG doses. Obviously, only a $10 \%$ increase in the fEPSP slope occurred after tetanic stimulation. The time course of the potentiation was similar to the one recorded for the PS. Two hours after the high-frequency shocks, the fEPSP declined back to baseline levels. Group comparison revealed significant differences between controls and drug-treated animals from $2.5 \mathrm{hr}$ on (* in Fig. $4 D ; p<0.05$ ). Surprisingly, 24 $\mathrm{hr}$ after tetanus, the fEPSP dropped to $80 \%$. We have no conclusive explanation for this observation.

Intracerebroventricular injection of the high concentration of
MCPG 30 min prior to tetanic stimulation completely abolishes the potentiation (Fig. $4 B, F)$. A very small increase $(20-30 \%)$ in PS amplitude was recorded up to $15 \mathrm{~min}$ posttetanically. Afterward, responses to test stimuli fell back to baseline levels and remained stable over $4 \mathrm{hr}$. Figure $4 F$ shows original traces recorded from dentate granule cells at different time points either prior to or after tetanization. They also indicate that shortly after the high-frequency train a small increase in PS amplitude occurs, which is normally of short duration.

In order to determine the time course of the effectiveness of the mGluR antagonist, we also applied MCPG $24 \mathrm{hr}$ prior to tetanization (data not shown here). We found only a slight difference in the time course of LTP as compared to the vehicleinjected animals. This difference was not statistically significant. Shortly after tetanus the PS amplitude increases up to $250 \%$ and declines to potentiated values of $180 \%$ during $2 \mathrm{hr}$. Then the LTP remained stable at this level. We never observed a decline back to baseline levels, as seen in the MCPG group. 


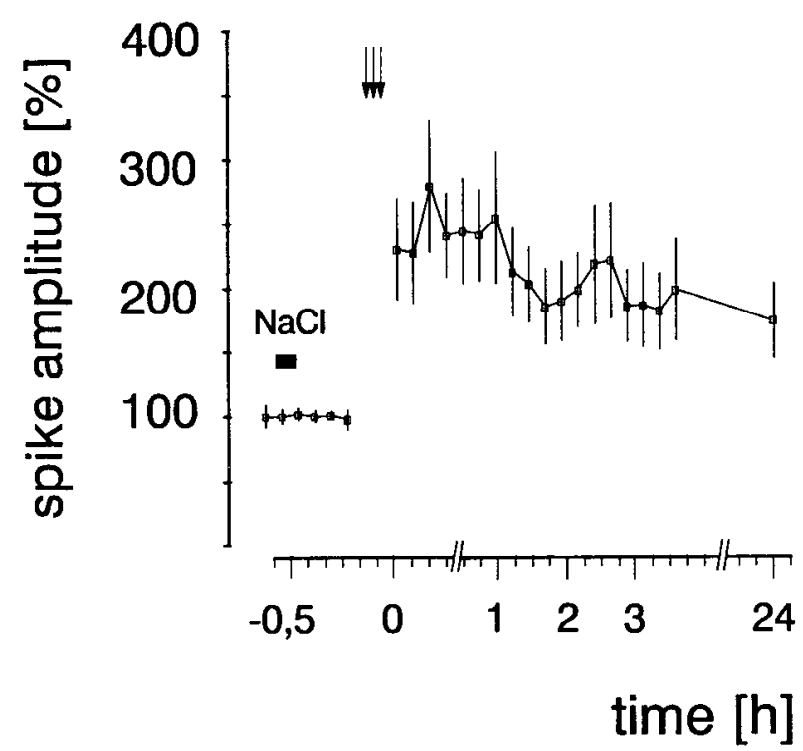

Figure 3. Effect of vehicle injection $(\mathrm{NaCl})$ on the time course of LTP in the dentate gyrus of freely moving rats. The vehicle was administered by use of a intraventricular microsyringe $(n=7) 30 \mathrm{~min}$ prior to tetanization. The data were plotted as average percentage change from baseline responses. Error bars indicate SEM; triple arrows mark the time point of tetanic stimulation ( 10 bursts of 15 stimuli, $200 \mathrm{~Hz}, 0.2 \mathrm{msec}$ duration, interburst interval of $10 \mathrm{sec}$. The vehicle obviously had no influence on induction, magnitude, and duration of LTP. Following the tetanus the PS amplitude increases in magnitude up to $250-300 \%$. These values slightly decrease in time to $180-200 \%$ after $24 \mathrm{hr}$. The increase is statistically significant for all time points compared to baseline values.

\section{Effects of MCPG on preestablished LTP}

Work concerning the function of PKC in LTP has been controversial. Although it was reported that a permanent activation of PKC is required for the persistence of LTP (Malinow et al.,

Figure 4. Effect of MCPG applied intraventricularly 30 min prior to tetanus-induced I.TP. Two concentrations $(A, 20 \mathrm{mM}, n=7 ; B, 200$ $\mathrm{mm}, n=5$ ) were tested. The data were plotted as average percentage change from baseline responses. Error bars indicate SEM; triple arrows mark the time point of tetanic stimulation (for details of high-frequency bursts, see Materials and Methods). In $A$, a pronounced posttetanic potentiation occurred, which had the same magnitude as observed for the vehicle group (Fig. 3). The potentiation lasted for approximately 2$3 \mathrm{hr}$ with its peak briefly after the tetanus, and a steady decay back to baseline levels. A significant difference exists between the vehicle and the low MCPG group $2.5 \mathrm{hr}$ posttetanically (Mann-Whitney $U$ test, $p$ $<0.05$ ). According to a recent report (Bliss and Collingridge, 1993), this time course of potentiation might represent the STP component. Application of the 10-fold higher MCPG concentration completely blocks both LTP and STP in the dentate gyrus in vivo $(B)$. These data indicate a concentration-dependent action of MCPG. Higher concentrations seem to block some other receptors, although MCPG has a high affinity for mGluRs (Jane et al., 1993). In the $C$ and $D$, measures of the population fEPSPs are shown for both the vehicle-treated $(C, n=6)$ and low MCPG-treated $(D, n=6)$ groups. The time course of the fEPSP shows a small but persistent potentiation of $20 \%$ after tetanus in controls. The time course of the IEPSP potentiation in the MCPG-treated group resembles that of the PS. Shortly after tetanization the slope was potentiated, and declined back to baseline over $2 \mathrm{hr}$. Significant differences between controls and MCPG-treated animals are indicated by asterisks $(p<0.05)$. We have at present no conclusive explanation for the drop of the slope $24 \mathrm{hr}$ after tetanus in this group. Representative original traces of the MCPG group (low concentration of MCPG) are shown in $E$. No alterations in PS amplitude occurred after drug infusion $(b+m l)$
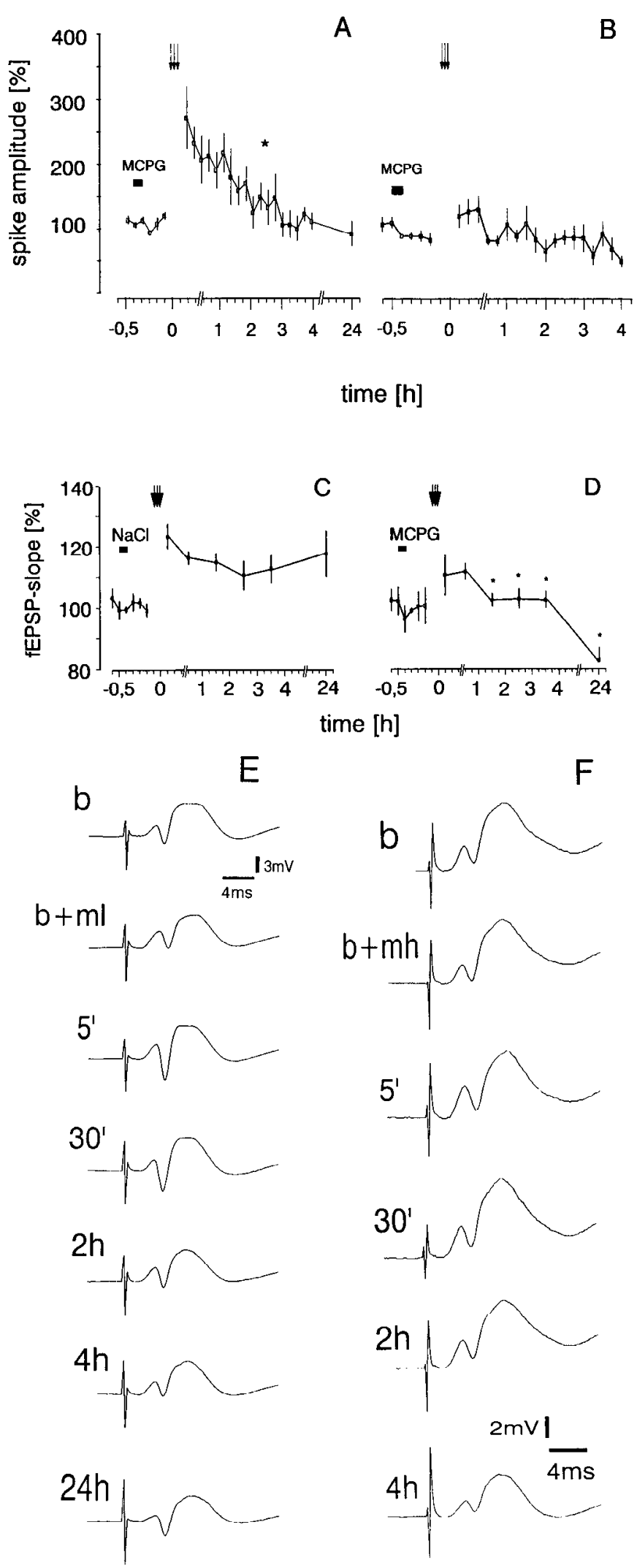

compared to baseline responses (b). Posttetanically, both PTP and the decremental STP were observed; then the PS amplitude fell back to baseline values ( $4 h ; 5^{\prime} / 30^{\prime}, 5 / 30 \mathrm{~min} ; 2 h / 4 h / 24 h, 2 / 4 / 24 \mathrm{hr}$ posttetanic). Representative original traces of the MCPG group (high concentration of MCPG) are summarized in $F$. No alterations in PS amplitude occurred after drug infusion $(b+m l)$ compared to baseline responses $(b)$. Only a small increase in the PS amplitude was registered $5 \mathrm{~min}\left(5^{\circ}\right)$ posttetanus. Afterward the potentials remained stable at baseline values. 


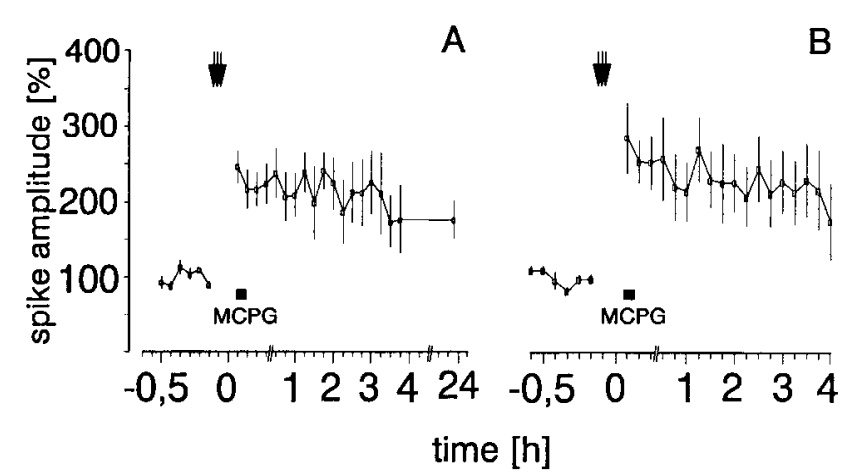

Figure 5. Effect of MCPG on preestablished LTP. A comparison of both low $(A, 20 \mathrm{mM}, n=7)$ and high $(B, 200 \mathrm{~mm}, n=6)$ concentration is shown. The data were plotted as average percentage change from baseline responses. Error bars indicate SEM; triple arrows mark the time point of tetanic stimulation. Both graphs demonstrate that MCPG administration $5 \mathrm{~min}$ after the high-frequency bursts does not alter the established LTP in duration and magnitude. These results indicate that induction of LTP at perforant path-dentate gyrus synapses in vivo requires the activation of mGluRs. Once activated, a block of mGluRs did not change the time course of established LTP. Moreover, these data suggest that normal cellular functions were not influenced by MCPG. It seems likely then that the complete block of potentiation in the highconcentration group was due to a block of the NMDA glutamate receptor subtype and not due to an influence on subsequent intracellular events.

1989), others have failed to inhibit preestablished LTP by applying the PKC antagonists $\mathrm{H}-7$ and polymyxin B 60 min after tetanization (Colley et al., 1990), as well as K-252 and staurosporine 60 or $180 \mathrm{~min}$ posttetanically (Matthies et al., 1991). Thus, it seems reasonable to ask whether the injection of an mGluR antagonist shortly after tetanic stimulation inhibits late phases of LTP. We conducted a series of experiments in which we applied $5 \mu$ l of MCPG 5 min posttetanically. Figure 5 summarizes the results obtained for both the low $(A)$ and the high $(B)$ concentration of MCPG applied intracerebroventricularly. Neither the time course nor the amplitude of the preestablished LTP was altered after drug treatment. This provides compelling

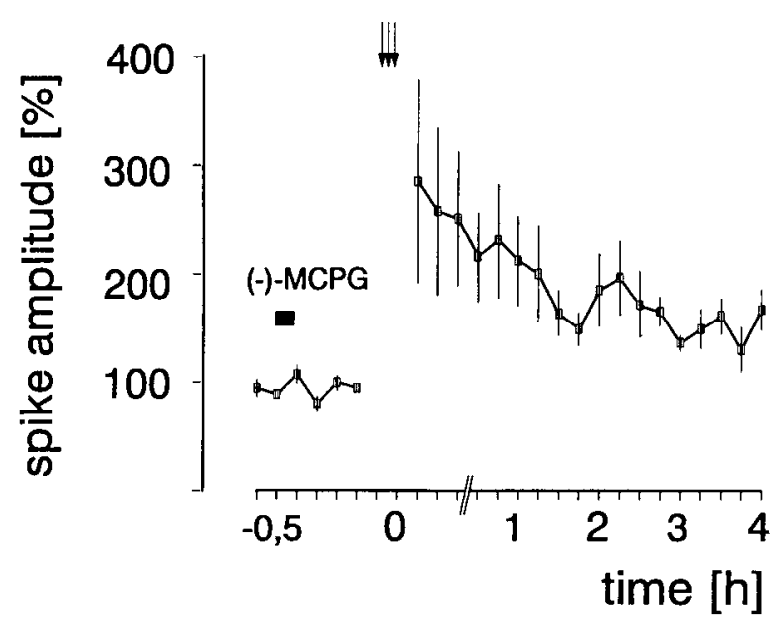

Figure 6. Effects of (-)-MCPG on induction and maintenance of LTP in the dentate gyrus in vivo. This isomer applied in the high concentration $(200 \mathrm{~mm} / 5 \mu \mathrm{l}) 30 \mathrm{~min}$ prior to tetanization has no effect on the time course of LTP $(n=6)$. Data were plotted as an average of the percentage change from baseline responses. Error bars indicate SEM; triple arrows mark the time point of tetanic stimulation. The time course of potentiation is similar to the one found in the vehicle-treated group. The decay in the first $2 \mathrm{hr}$ is not statistically significantly different from LTP controls (Mann-Whitney $U$ test, $p \gg 0.05$ ).

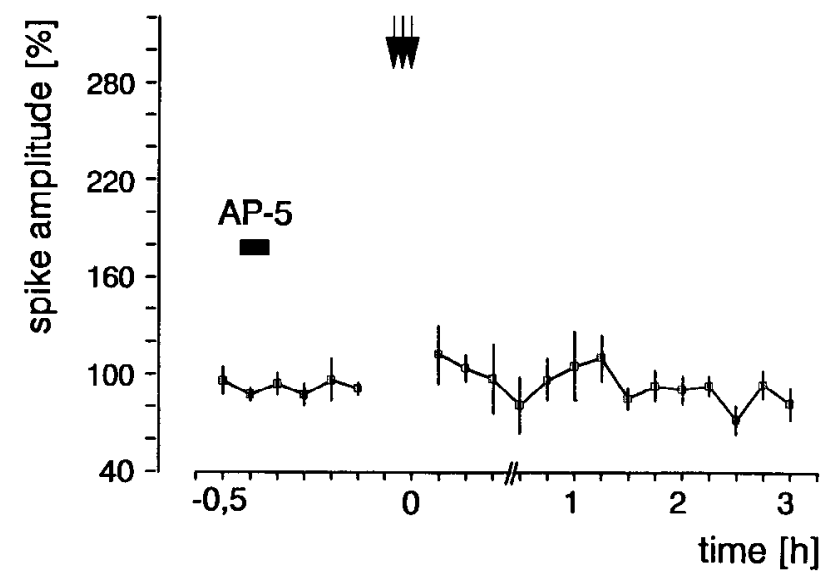

Figure 7. Effect of the NMDA receptor antagonist 2-amino-5-phosphonopentanoate $(A P-5 ; 20 \mathrm{~mm} / 5 \mu \mathrm{l})$ on LTP $(n=5)$. The data were plotted as average percentage change from baseline responses. Error bars indicate SEM; triple arrows mark the time point of tetanic stimulation. AP5 applied 30 min prior to tetanic stimulation completely blocks the potentiation. The time course was similar to the one found for the high concentration of MCPG (Fig. $4 B$ ). Therefore, one might suspect that MCPG in addition to its $M$ GluR antagonism also inhibits NMDA receptors. The fact that high concentrations of MCPG were required for this blockade suggests a concentration dependence of this effect, and further indicates that the affinity of the drug is high for mGluRs and lower for NMDA receptors.

evidence that the activation of $\mathrm{mGluR}$ during tetanic stimulation is required to induce a long-lasting LTP.

\section{Effect of the (-)-MCPG isomer on LTP}

Recently, it was shown by Jane et al. (1993) that the active isomer of $\mathrm{MCPG}$ was the $(+)$ form. We therefore analyzed whether the (-)-isomer of MCPG was without effect on induction and maintenance of LTP. (-)-MCPG, at $0.104 \mathrm{mg} / 5 \mu \mathrm{l}$, was injected intracerebroventricularly $30 \mathrm{~min}$ prior to tetanic stimulation. As shown in Figure 6, no alteration in the time course of LTP was observed. High-frequency shocks induced a stable and long-lasting increase in the PS amplitude with no difference from the vehicle-treated group. These results support the view that the $(+)-M C P G$ was the active isomer, and further indicate that all monitored effects of the racemic form were due to the action of $(+)-M C P G$.

\section{Effect of AP5 on LTP induction}

It is well known that NMDA receptor activation is required for the induction of LTP in the hippocampus in vitro (Collingridge et al., 1988) and in vivo (Morris et al., 1986). As we found a complete block of LTP due to the intracerebroventricular injection of high doses of MCPG, we investigated the effect of AP5, an NMDA receptor antagonist, for a more detailed comparison.

As indicated in Figure 7, AP5 $(n=5)$ completely blocks the induction of LTP in a manner similar to that described for the high concentration of MCPG. No potentiation of the PS amplitude occurred in response to tetanic stimulation. Comparing this effect with the MCPG data, one would suspect that the high concentration of MCPG also, at least partially, blocks NMDA receptors.

\section{Effects of MCPG on PPI hydrolysis in hippocampal slices}

Since electrophysiological experiments indicate that MCPG selectively blocks mGluRs, we analyzed which mGluR subtypes 


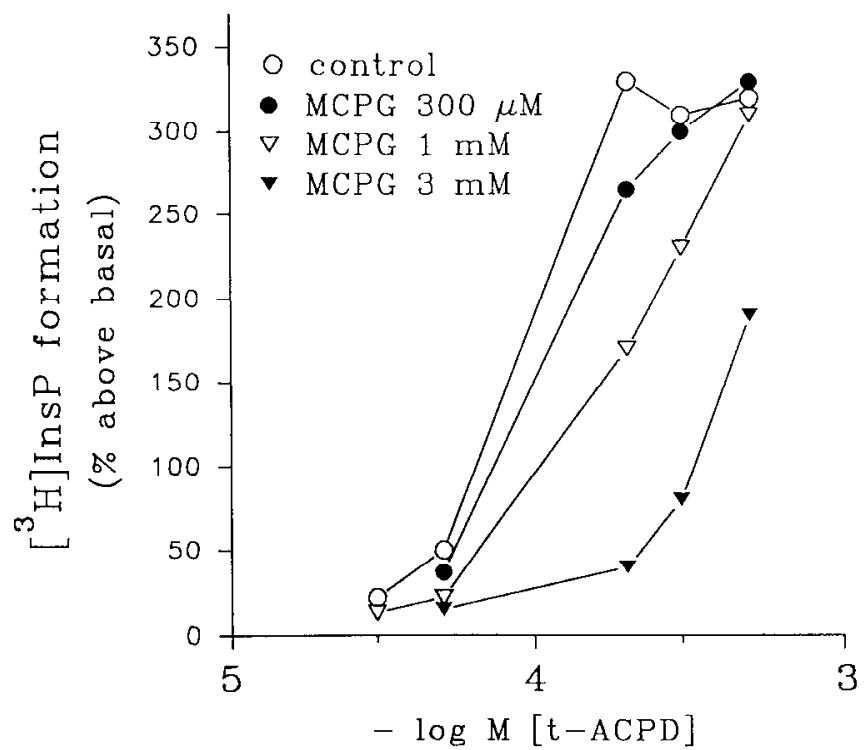

Figure 8. Action of MCPG on PPI hydrolysis in hippocampal slices. $1 S, 3 R$-ACPD induced a concentration-dependent increase in the hydrolysis of phosphoinositol. This increase was attenuated by MCPG in a concentration-dependent manner. All measurements were done in triplicate. For details of the biochemical procedures, see Materials and Methods.

were antagonized by MCPG. This is of particular interest because in the dentate gyrus several different mGluR subtypes are present (Abe et al., 1992; Tanabe et al., 1992; Ohishi et al., 1993a,b).

As summarizcd in Figure 8, we found that ACPD-induced PPI hydrolysis was attenuated by MCPG in a concentrationdependent fashion, most clearly evident at concentrations of 1 mM or higher. These data suggest that MCPG acts as a competitive antagonist of the mGluR 1 and/or mGluR5 subtypes.

\section{Effects of MCPG on mGluR subtypes negatively coupled to cAMP formation}

To assess further whether inhibition of other mGluR subtypes that are negatively linked to cAMP formation could also contribute to the inhibition of LTP, we analyzed the effect of MCPG on forskolin-stimulated cAMP formation using a concentration of MCPG ( $1 \mathrm{~mm}$ ) that clearly blocks PPI hydrolysis in the same preparation.

We found (Fig. 9) that ACPD (100 $\mu \mathrm{M})$ attenuated the forskolin-stimulated $(30 \mu \mathrm{M}) \mathrm{cAMP}$ formation by up to $50 \%$. This inhibition was not affected by the application of MCPG ( $1 \mathrm{~mm}$ ), although this concentration potently blocked PPI hydrolysis (Fig. 8). These results provide conclusive evidence that MCPG predominantly blocks mGluRs coupled to PPI hydrolysis in hippocampal slice preparations. However, a significant disinhibition of the CAMP formation at higher concentrations of MCPG cannot be excluded.

\section{Discussion}

\section{Long-term potentiation (LTP) in the hippocampus}

Long-term potentiation as a form of activity-dependent synaptic plasticity is widely accepted as a model to investigate the cellular mechanisms of learning and memory. It is a widespread phenomenon within the limbic forebrain, which shows striking differences between pathways. However, the hippocampal for-

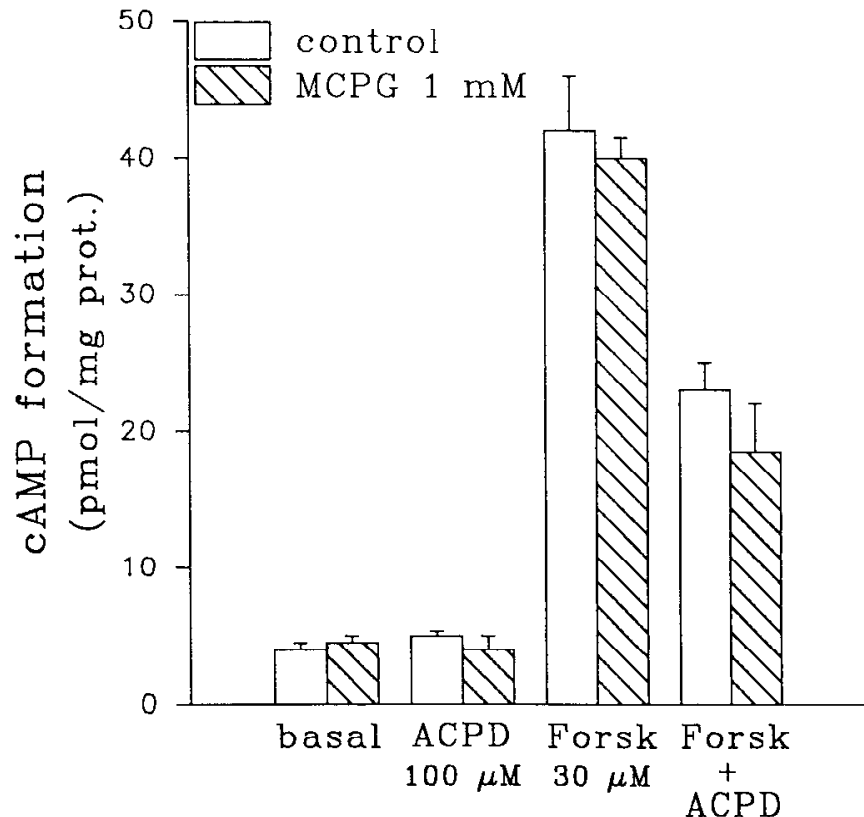

Figure 9. Action of MCPG on trans-ACPD-attenuated, forskolin-induced cAMP formation in hippocampal slices. Forskolin-stimulated cAMP formation was inhibited by the activation of mGluRs due to application of $1 S, 3 R$-ACPD. Administration of MCPG has no effect on ACPD-dependent inhibition of CAMP production at a concentration that is effective in blocking ACPD-induced PPI hydrolysis (1 mM). All measurements were done in triplicate. For details of the biochemical procedures, see Materials and Methods.

mation is the region with the lowest threshold for producing LTP and expresses the strongest and longest-lasting potentiation (Racine et al., 1983). Expression of LTP in the dentate gyrus depends, in part, upon the number of afferents activated by the stimulation train (McNaughton et al., 1978), upon the activation of NMDA receptors during brief high-frequency tetanization (Collingridge et al., 1983; Harris et al., 1984; Morris et al., 1986), and upon the behavioral state of the animal (Buszaki et al., 1981; Hargreaves et al., 1990; Huang et al., 1992). Additionally, NMDA receptor-independent LTP also exists, especially in hippocampal CA3 (Harris and Cotman, 1986; Grover and Teyler, 1990, 1992; Zalutsky and Nicoll, 1990; Aniksztejn and BenAri, 1991; Weisskopf et al., 1993).

Although there is a simultaneous increase in IEPSP slope and PS amplitude after tetanization (Bliss and Gardner-Medwin, 1973; Anderson et al., 1980; Klaucnik and Phillips, 1991), the EPSP potentiation is small compared to PS potentiation (Bliss and Gardner-Medwin, 1973; Klaucnik and Phillips, 1991). We found that although the potentiation of the fEPSP was not high, it remained stable under our experimental conditions for $1 \mathrm{~d}$ or more.

\section{Multiple $m$ GluRs}

Metabotropic glutamate receptors (mGluRs) have recently been discovered as a new family of G-protein-coupled receptors (for review, see Schoepp and Conn, 1993), and activation of a postsynaptic G-protein is involved in LTP in hippocampal CA1 (Ballyk and Goh, 1993). Applying the selective mGluR agonist trans-ACPD, mGluRs were found to be linked to multiple second messenger systems. Molecular cloning studies have revealed at least seven different mGluR subtypes (Masu et al., 1991; Abe 
et al., 1992; Nakanishi, 1992; Tanabe et al., 1992), from which mGluR 1 and mGluR5 are coupled to the phosphoinositide (PPI) hydrolysis via phospholipase C (Palmer et al., 1989; Schoepp et al., 1990a,b; Conn and Desai, 1991). In contrast, activation of mGluR2-mGluR4, mGluR6, and mGluR7 decrease forskolin-stimulated cAMP formation (Tanabe et al., 1992). Additionally, basal cAMP levels are increased after mGluR activation (Schoepp et al., 1992; Winder and Conn, 1992) and mGluR activation modulates several ion channels (Lester and Jahr, 1990). Very recently, it was shown that mGluRs in addition upregulate postsynaptic protein synthesis via the phosphatidylinositol-coupled second messenger system (Weiler and Greenough, 1993) and activate phospholipase D via an AP3-resistant mechanism (Boss and Conn, 1992; Holler et al., 1993).

It is well known that L-AP3 as a mGluR antagonist in LTP studies acts on mGluRs linked to phosphoinositide breakdown. This hydrolysis is potently inhibited by L-AP3 (Schoepp et al., $1990 \mathrm{a}, \mathrm{b}$ ) as well as by MCPG in hippocampal slice preparations (present results) and cortical pyramidal cells (Birse et al., 1993). Interestingly, MCPG does not affect forskolin-stimulated cAMP formation at concentrations that clearly suppress PPI hydrolysis in the hippocampus (present results). Although an effect on cAMP-coupled mGluRs at higher concentrations cannot be excluded here, higher doses of MCPG may also lead to unspecific effects, which in turn may influence the action of mGluR-coupled second messenger systems. It was until now unclear whether MCPG also acts on other G-protein-coupled receptors. Indirectly, MCPG block of mGluRs may modulate other transmitter receptors as well via polysynaptic mechanisms. Detailed information about such influences are not so far available.

In contrast to this report, there is recent evidence that MCPG is also an effective antagonist of mGluRs negatively coupled to cAMP formation. Similar concentrations of $\mathrm{MCPG}$ as reported here ( $1 \mathrm{mM}$ ) were shown to disinhibit forskolin-stimulated cAMP formation in guinea pig cortical slices, an effect proposed to be mediated by presynaptically located mGlu autoreceptors (socalled I-AP4 receptors) (Roberts et al., 1993). Moreover, transACPD-facilitated, $\mathrm{Ca}^{2+}$-dependent glutamate release was blocked by MCPG in cerebrocortical synaptosomes (SanchezPrieto et al., 1993) and MCPG was reported to block long-term depression (LTD) in the striatal slice preparation via a presynaptic mechanism (Lovinger, 1993).

\section{$M C P G$ and the physiology of mGluRs}

Beside these biochemical data, ACPD application has uncovered a variety of effects of mGluRs on membrane ion fluxes and synaptic events, such as depolarization and excitation (Curry et al., 1987; Charpak et al., 1990; Ishida et al., 1990, 1993; Stratton et al., 1990; Salt and Eaton, 1991), as well as the inhibition of $\mathrm{Ca}^{2+}$-dependent $\mathrm{K}^{+}$currents resulting in a decrease of the afterhyperpolarization (Stratton et al., 1989; Baskys et al., 1990) that normally follows action potentials or trains of action potentials, or a hyperpolarization (Harvey et al., 1991). With respect to the mechanisms of LTP, ACPD was found to potentiate NMDA-induced responses (Collingridge et al., 1988; Aniksztejn et al., 1991; Ben-Ari et al., 1992), possibly via PKC and/or Ca/ calmodulin kinase II-induced phosphorylation (Kitamura et al., 1993), or to reduce synaptic excitation (Baskys and Malenka, 1991; Pook et al., 1992). Contrasting results were obtained by others. Whereas focal application of 1-oleoyl-2-acetylglycerol (OAG), an activator of PKC, suppressed NMDA receptor-me- diated responses in CAl hippocampal neurons (Markram and Segal, 1992), protein kinase inhibitors, such as staurosporine and $\mathrm{K}-252 \mathrm{~b}$, did not affect potentiation of NMDA responses by ACPD (Harvey and Collingridge, 1993).

Additionally, ACPD was described to induce I.TP-like phenomena without previous activation of NMDA receptors (Bortolotto and Collingridge, 1992, 1993) or to facilitate electrically induced LTP (Otani and Ben-Ari, 1991; McGuinnes et al., 1992; Behnisch and Reymann, 1993). It thus seems possible that both activation or inhibition of mGluRs may influence the synaptic transmission of glutamatergic synapses. To test whether mGluRs contribute to normal synaptic transmission, we delivered the drug intracerebroventricularly and recorded the field PS amplitude under baseline conditions for up to $24 \mathrm{hr}$. Neither in the low nor in the high concentration of MCPG was any change observed in extracellularly recorded potentials compared to the preceding baseline level. We therefore conclude that MCPG has no influence on normal synaptic transmission, that is, on presynaptic glutamate rclcase or postsynaptic AMPA rcceptor sensitivity, in the dentate gyrus of freely moving rats.

Interestingly, mGluR stimulation by $1 S, 3 R-A C P D$ is well known to reduce excitatory potentials at glutamatergic synapses in the hippocampus and other brain regions as well (Lovinger, 1991; Rainnie and Shinnick-Gallagher, 1992). This effect is believed to be due to the activation of presynaptic mGlu autoreceptors, since ACPD does not alter current or voltage responses to exogenously applied excitatory amino acids (Baskys and Malenka, 1991). There is also evidence for presynaptically located mGluRs at corticostriatal synapses (Lovinger et al., 1992) and in hippocampal regions (Baskys and Malenka, 1991). The mechanism of presynaptic inhibition is still a matter of debate. One hypothesis holds that this decrease in glutamate release is mediated by the inhibition of $\mathrm{Ca}^{2+}$ channels in the axon terminal (Sahara and Westbrook, 1991; Lonart et al., 1993). Others stated that presynaptic activation of mGluRs, which facilitatc glutamate release, is mediated by a transient increase in diacylglycerol levels mediated by mGluRs coupled to PPI hydrolysis (Goh and Ballyk, 1993; Sanchez-Prieto et al., 1993).

Moreover, the effects of mGluR activation on hippocampal interneurons have to be considered. ACPD may either cause large inhibitory postsynaptic potentials (IPSPs) in conjunction with tetanic stimulation, thus suggesting that mGluRs can excite inhibitory cells, which then generate large IPSPs (Miles and Poncer, 1993), or generate a long-term depression of the GABAergic inhibition, thereby enhancing synaptic excitability in the hippocampal formation (Hayashi et al., 1993; Liu et al., 1993). However, since basal responses to test stimuli were unchanged after MCPG application, it also seems unlikely that inhibitory circuits were substantially affected by the drug. Although studies on mRNA for mGluRs revealed this glutamate receptor subtype to be strongly expressed in hippocampal inhibitory cells, further investigations are needed to determine the mGluR subspecies mediating these effects.

The fact that the basal responses of the dentate granule cells were not altered after drug application thus could be interpreted in two ways. First, as we found no alteration of basal responses to test stimuli, mGluRs seem to be less important for normal synaptic responses or the interaction is too weak to influence transmitter release or AMPA receptor sensitivity. Second, and this is with respect to inhibition of LTP, different mGluRs may be activated during different physiological activity states; that 
is, the high-frequency train may activate a different subset of mGluRs than normal test pulses.

\section{Effects of $M C P G$ on induction and maintenance of hippocampal LTP}

The importance of mGluRs in LTP was supported recently by Bortolotto and Collingridge $(1992,1993)$, who induced a stable form of LTP without the preceding STP component in the CA1 region in vitro by activation of mGluRs via $1 S, 3 R$-ACPD. Results reported by Baskys and Malenka (1991) contrasted with those of our own laboratory (Behnisch and Reymann, 1993). We found no effect of $t$-ACPD on synaptic transmission. This could be due to an age dependence of the mGluR activation, as recently shown by Trommer et al. (1993). They found that ACPD decreases PS amplitudes in CA1 and dentate gyrus in 10-15-d-old rats but enhances PS amplitudes in older animals.

When combining the application of ACPD with a concomitant activation of NMDA receptors and low-frequency stimulation of afferent fibers, a long-lasting enhancement of synaptic responses in CA1 results (Radpour and Thomson, 1992; Behnisch and Reymann, 1993).

As was shown by Bashir et al. (1993) in CAl in vitro and by Riedel and Reymann (1993) in the dentate gyrus in vivo, MCPG selectively impairs the long-lasting potentiation without interfering with short-term enhancement of synaptic efficacy. In the low MCPG concentration group, we found STP declining back to baseline values after $2-3 \mathrm{hr}$. Bashir and colleagues provided persuasive evidence that MCPCr does not affect other glutamate receptors of the AMPA and NMDA type. It is unclear at present whether this also holds for the dentate gyrus and for all concentrations.

To evaluate in vivo effects of higher MCPG concentrations, we also delivered MCPG at a dose that was comparable (i.e., $500 \mu \mathrm{M}$ if one assumes a uniform distribution of the drug and the brain to be $2 \mathrm{ml}$ ) to the one utilized by Bashir et al. Interestingly, we found a complete block of a tetanus-induced potentiation in the dentate gyrus in vivo. Since this blocking action is comparable to the one found after application of AP5, one could question the absolute selectivity of MCPG on mGluRs. Very recently, Jane et al. (1993) analyzed the stereospecific antagonism of the (+)- versus (-)-isomer of MCPG on $1 S, 3 R$ ACPD-induced effects in rat thalamic and motoncurons. They convincingly showed (and we present indirect evidence here) that the $(+)$ form is the active one, which also, at least partially, antagonizes NMDA-induced responses. Consequently, our results for the high MCPG concentration could be interpreted as a combined block of both mGluRs and NMDA receptors, thereby preventing the induction of STP and LTP. Nevertheless, others excluded the possibility of an antagonism of MCPG on NMDA receptors (Eaton et al., 1993), as they found no depressing effect of MCPG in a concentration of $1 \mathrm{~mm}$ on depolarizations induced by NMDA and AMPA in rat thalamic and motoneurons. However, the lower concentration (concentration A in our experiments) may selectively block mGluRs, since tetanus administration results in a short-lasting and decremental STP, which requires the activation of NMDA receptors (Collingridge et al., 1983).

How could our results be interpreted in this context? The differences occurring could first be due to a variance in the distribution of the different mGluR subtypes in the analyzed brain structures. Second, the intracerebroventricular injection of a high concentration of drugs may result in a nonuniform distribution of the compound in the brain that may be temporarily higher in the hippocampal formation that is located close to the ventricle. One thus cannot exactly determine the effective drug concentration at the recording site. Third, a different stimulation pattern was used in this study, which may also cause such a discrepancy. The importance of the tetanization parameter on MCPG action was very recently demonstrated by Brown et al. (1994), who successfully blocked LTP in CA1 in vitro using the Bashir parameters, while providing convincing evidence that MCPG does not block CA1 LTP induced by $\theta$-burst-like tetanization. Therefore, one could suggest that mGluR activation depends on release of glutamate from the presynaptic terminal, thus reflecting a threshold for activation of different mGluR subtypes. This is corroborated by the dose-dependent inhibition of LTP by MCPG. Similarly, such a dose-dependent block of LTP was described for the NMDA receptor antagonist AP5 in hippocampal CAl (Grover and Teyler, 1994). Finally, such discrepancies could evolve from extrahippocampal influences, which were mostly cut in slice preparations and were left intact in freely moving animals.

Similar to the concentration-dependent effect of MCPG described here, the PKC inhibitor polymyxin B produced a concentration-dependent decay of the potentiation response, and at high concentrations also blocks the initial rise of potentiation (Collcy ct al., 1990). This observation was thought to be due to the ability of polymyxin $\mathrm{B}$ at higher doses to inhibit the $\mathrm{Ca} /$ calmodulin-dependent kinase II, thereby blocking initial potentiation (Reymann et al., 1988). Very recently a block of LTP (not STP) was demonstrated by the application of anti-phosphatidylinositol-4,5-bisphosphate antibodies, which inhibit the substrate of phospholipase C (Tsubokawa et al., 1993). Tetanic stimulation elicited only a decremental potentiation, gradually declining back to baseline in $1 \mathrm{hr}$, thus indicating that activation of mGluRs coupled to PPI hydrolysis is essential for triggering LTP. That only a high concentration of MCPG was effective against ACPD-induced PPI hydrolysis in the present work can be explained most easily by methodical differences between the physiological in vivo approach and the biochemical slice technique.

Transient PKC activation contributes to the transformation from STP into LTP (Otani ct al., 1993), sincc inhibitors of PKC block different phases of hippocampal LTP (Reymann et al., 1988; Malenka et al., 1989; Colley et al., 1990; Matthies et al., 1991; Huang et al., 1992). Normal PKC modulation seems to be prevented by MCPG, since it effectively blocks PPI hydrolysis in hippocampal slices (present results), which is thought to be a prerequisite for PKC activation. Very recently, we found a translocation of the postsynaptic $\gamma$ PKC subtype but not the $\alpha / \beta$ PKC into the cytosolic fraction $15 \mathrm{~min}$ after induction of tetanus-induced LTP in the dentate gyrus in vivo (Angenstein et al., 1994). Whether this translocation is important for LTP to occur and whether it can be blocked by pretetanic injection of MCPG have to be evaluated in further experiments.

Earlier work on LTP has already implicated a role of glutamate receptors in postsynaptic expression of LTP (Lynch and Baudry, 1983). A specific increase in postsynaptic non-NMDA receptor-mediated EPSPs was found due to tetanic shocks (Kauer et al., 1988; Muller et al., 1989; Nicoll et al., 1990; Perkel and Nicoll, 1993). The increase in AMPA receptor sensitivity (Davies et al., 1989) is blocked by MCPG in hippocampal CA1 in 
vitro in a concentration similar to the high dose utilized in this study (Sergueeva et al., 1993), thus suggesting an involvement of mGluRs in the regulation of AMPA sensitivity.

We are far from a complete understanding of the role of mGluRs in LTP processes. First of all, high-affinity, selective antagonists are still not availablc. Using AP3 as well as $\mathrm{AP} 4$, it was shown for the first time that late phases of tetanus-induced LTP depend on mGluR activation (Reymann and Matthies, 1989; Behnisch et al., 1991; Izumi et al., 1991). Better pharmacological tools have been awaited since. Second, the relative diversity of mGluRs and their involvement in a variety of second messenger cascades has obscured a clear understanding of their basal function as well as their role in LTP. Our data suppose that possible target candidates for the action of MCPG are those mGluR subtypes coupled to phosphoinositide hydrolysis, which, by activating a protein kinase, can enhance NMDA and AMPA currents (Collingridge et al., 1988; Reymann et al., 1990; Aniksztejn et al., 1992). Activation of these mGluRs can thus enable the induction of STP and LTP (McGuinnes et al., 1991a,b; Behnisch and Reymann, 1993; Otani et al., 1993).

Our results thus support the recent suggestion, by Bashir et al. (1993) and our own group (Behnisch and Reymann, 1993), that the activation of both $m$ GluRs and NMDA receptors during delivery of the brief high-frequency bursts elicit LTP, since MCPG injection $5 \mathrm{~min}$ after tetanization does not alter the time course of preestablished LTP. Further investigations have to elucidate whether other second messenger pathways may be affected by MCPG application as well.

\section{References}

Abc T, Sugihara H, Nawa H, Shigemoto R, Mizuno N, Nakanishi S (1992) Molecular characterization of a novel metabotropic glutamate receptor mGluR5 coupled to inositol phosphate/ $\mathrm{Ca}^{2+}$ signal transduction. J Biol Chem 267:13361-13368.

Andersen P, Sundberg SH, Sveen O, Swann JW, Wigström H (1980) Possible mechanism for long-lasting potentiation of synaptic transmission in hippocampal slices from guinea-pigs. J Physiol (Lond) 302: $463-482$.

Angenstein F, Riedel G, Reymann KG, Staak S (1994) Hippocampal long-term potentiation in vivo induces translocation of protein kinase C. Neuroreport 5:381-384.

Aniksztejn L, Ben-Ari Y (1991) Novel form of long-term potentiation produced by a $\mathrm{K}^{+}$channel blocker in the hippocampus. Nature 349 : 67-69.

Aniksztcjn L, Bregestovski P, Ben-Ari Y (1991) Sclcctive activation of quisqualate metabotropic receptor potentiates NMDA but not AMPA responses. Eur J Pharmacol 205:327-328.

Aniksztejn L, Otani S, Ben-Ari Y (1992) Quisqualate metabotropic receptors modulate NMDA currents and facilitate induction of longterm potentiation through protein kinase C. Eur J Neurosci 4:500505.

Ballyk BA, Goh JW (1993) A postsynaptic G-protein in hippocampal long-term potentiation. Brain Res 611:81-86.

Bashir ZI, Bortolotto ZA, Davies CH, Berretta N, Irving AJ, Seal AJ, Henley JM, Jane DE, Watkins JC, Collingridge GL (1993) The synaptic activation of glutamate metabotropic receptors is necessary for the induction of LTP in the hippocampus. Nature 363:347-350.

Baskys A, Malenka RC (1991) Trans-ACPD depresses synaptic transmission in the hippocampus. Eur J Pharmacol 193:131-132.

Baskys A, Bernstein NK, Barolet AW, Carlen PL (1990) NMDA and quisqualate reduce $\mathrm{Ca}$-dependent $\mathrm{K}^{+}$current by a protein kinase mediated mechanism. Neurosci Lett 112:76-81.

Behnisch T, Reymann KG (1993) Co-activation of metabotropic glutamate and $N$-methyl-D-aspartate receptors is involved in mechanisms of long-term potentiation maintenance in rat hippocampal CA 1 neurons. Neuroscience 54:37-48.

Behnisch T, Fedorov K, Reymann KG (1991) L-2-Amino-3-phosphonopropionate blocks late synaptic long-term potentiation. Neuroreport 2:386-388.
Ben-Ari Y, Aniksztejn L, Bregestovski P (1992) Protein kinase C modulation of NMDA currents: an important link for LTP induction. Trends Neurosci 15:333-339.

Berridge MJ, Downes CP, Hanley MR (1982) Lithium amplifies agonist-dependent phosphatidylinositol responses in brain and salivary glands. Biochem J 206:587-597.

Bindman LJ, Murphy KPSJ, Pockett S (1988) Postsynaptic control of the induction of long-term changes in efficacy of transmission at neocortical synapses in slices of the rat brain. J Neurophysiol 60:10531065.

Birse EF, Eaton SA, Jane DE, Jones PLStJ, Porter RHP, Pook PC-K, Sunter DC, Udvarhelyi PM, Wharton B, Roberts PJ, Salt TE, Watkins JC (1993) Phenylglycine derivatives as new pharmacological tools for investigating the role of metabotropic glutamate receptors in the central nervous system. Neuroscience 52:481-488.

Bliss TVP, Collingridge GL (1993) A synaptic model for memory: long-term potentiation in the hippocampus. Nature 361:31-39.

Bliss TVP, Gardner-Medwin AR (1973) Long-lasting potentiation of synaptic transmission in the dentate area of the unanesthetized rabbit following stimulation of the perforant path. J Physiol (Lond) 232: 357-374.

Bliss TVP, Lomo T (1973) Long-lasting potentiation of synaptic transmission in the dentate area of the anesthetized rabbit following stimulation of the perforant path. J Physiol (Lond) 232:331-356.

Bliss TVP, Lynch M (1988) Long-term potentiation of synaptic transmission in the hippocampus: properties and mechanisms. In: Neurology and neurobiology, Vol 35, Long-term potentiation: from biophysics to behavior (Landfield PW, Deadwyler SA, eds), pp 3-72. New York: Liss.

Bortolotto ZA, Collingridge GL (1992) Activation of glutamate metabotropic receptors induces long-term potentiation. Eur J Pharmacol 214:297-298.

Bortolotto ZA, Collingridge GL (1993) Characterization of LTP induced by the activation of glutamate metabotropic receptors in area CA1 of the hippocampus. Neuropharmacology 32:1-9.

Boss V, Conn PJ (1992) Metabotropic excitatory amino acid receptor activation stimulates phospholipase D in hippocampal slices. J Neurochem 59:2340-2343.

Brown RE, Rabe H, Reymann KG (1994) (RS)- $\alpha$-methyl-4-carboxyphenylglycine (MCPG) does not block theta-burst induced long-term potentiation in area CAl of rat hippocampal slices. Neurosci Lett 170:17-21.

Buzsaki G, Grastyan E, Czopf G, Kellenyi L, Prohaska O (1981) Changes in neuronal transmission in the rat hippocampus during behavior. Brain Res 225:235-247.

Casabona G, Genazzani AA, Di Stefano M, Sortino MA, Nicoletti F (1992) Developmental changes in the modulation of cyclic AMP formation by the metabotropic glutamate receptor agonist $1 S, 3 R$ aminocyclopentane-1,3-dicarboxylic acid in brain slices. J Neurochem 59:1161-1163.

Charpak S, Gähwiler BH, Do KQ, Knöpfel T (1990) Potassium conductances in hippocampal neurons blocked by excitatory amino-acid transmitters. Nature 347:765-767.

Colley PA, Sheu F-S, Routtenberg A (1990) Inhibition of protein kinase C blocks two components of LTP persistence, leaving initial potentiation intact. J Neurosci 10:3353-3360.

Collingridge GL, Kehl SJ, McLennan H (1983) Excitatory amino acids in synaptic transmission in the Schaffer collateral-commissural pathway of the rat hippocampus. J Physiol (Lond) 342:33-46.

Collingridge GL, Herron CE, Lester RAJ (1988) Synaptic activation of $N$-methyl-D-aspartate receptors in the Schaffer collateral-commissural pathway of rat hippocampus. J Physiol (Lond) 399:288-300.

Conn PJ, Desai MA (1991) Pharmacology and physiology of metabotropic glutamate receptors in mammalian central nervous system. Drug Dev Res 24:207-229.

Curry K, Magnusson DSK, McLennan H, Pect MJ (1987) Excitation of rat hippocampal neurones by the stereoisomeres of cis- and trans1-amino-1,3-cyclopentane dicarboxylate. Can J Physiol Pharmacol 65:2196-2201.

Davies SN, Lester RAJ, Reymann KG, Collingridge GL (1989) Temporally distinct pre- and post-synaptic mechanisms maintain longterm potentiation. Nature 338:500-503.

Desai MA, Conn J (1991) Excitatory effects of ACPD receptor activation in the hippocampus are mediated by direct effects on pyramidal cells and blockade of synaptic inhibition. J Neurophysiol 66:40-52.

Eaton SA, Jane DE, Jones PLStJ, Porter RHP, Pook PC-K, Sunter DC, 
Udvarhelyi PM, Roberts PJ, Salt TE, Watkins JC (1993) Competitive antagonism at metabotropic glutamate receptors by $(S)$-4-carboxyphenylglycine and (RS)- $\alpha$-carboxyphenylglycine. Eur J Pharmacol 244:195-197.

Gennazzani AA, Casabona G, L'Episcopo MR, Condorelli DF, Dell'Albani P, Shinozaki H, Nicoletti F (1993) Characterization of metabotropic glutamate receptors negatively linked to adenylyl cyclase in brain slices. Brain Res 622:132-138.

Goh JW, Ballyk BA (1993) A cAMP-linked metabotropic glutamate receptor in the hippocampus. Neuroreport 4:454-456.

Grover LM, Teyler TJ (1990) Two components of long-term potentiation induced by different pattern of afferent activation. Nature 347 : $477-479$.

Grover LM, Teyler TJ (1992) $N$-methyl-D-aspartate receptor-independent long-term potentiation in area $\mathrm{CA} 1$ of rat hippocampus: input-specific induction and preclusion in a non-tetanized pathway. Neuroscience 49:7-11.

Grover IM, Teyler TJ (1994) Activation of NMDA receptors in hippocampal area CAl by low and high frequency orthodromic stimulation and their contribution to induction of long-term potentiation. Synapse 16:66-75.

Hargreaves EL, Cain DL, Vanderwolf CH (1990) Learning and behavioral long-term potentiation: importance of controlling for motor activity. J Neurosci 10:1472-1478.

Harris EC, Cotman CW (1986) Long-term potentiation of guinea pig mossy fiber responses is not blocked by $N$-methyl-D-aspartate antagonists. Neurosci Lett 70:132-137.

Harris EC, Ganong AH, Cotman CW (1984) Long-term potentiation in the hippocampus involves activation of $N$-methyl-D-aspartate receptors. Brain Res 323:132-137.

Harvey J, Collingridge GL (1993) Signal transduction pathways involved in the acute potentiation of NMDA responses by $1 S, 3 R$ ACPD in rat hippocampal slices. Br J Pharmacol 109:1085-1090.

Harvey J, Frenguelli BG, Sunter DC, Watkins JC, Collingridge GL (1991) The actions of $1 S, 3 R$-ACPD, a glutamate metabotropic receptor agonist, in area CAl of rat hippocampus. Br J Pharmacol 104: $75 \mathrm{P}$.

Hayashi Y, Momiyoma A, Takahashi T, Ohishi H, Ogawa-Meguro R, Shigemoto R, Mizuno N, Nakanishi S (1993) Role of metabotropic glutamate receptor in synaptic modulation in the accessory olfactory bulb. Nature 366:687-690.

Holler T, Klein J, Löffelholz K (1993) Glutamate activates phospholipase D in rat hippocampus. Funct Neurol [Suppl] 8:26.

Huang YY, Colino A, Selig DK, Malenka RC (1992a) The influence of prior synaptic activity on the induction of long-term potentiation. Science 255:730-733.

Huang YY, Colley PA, Routtenberg A (1992b) Postsynaptic then presynaptic protein kinase $\mathrm{C}$ activity may be necessary for long-term potentiation. Neuroscience 49:819-827.

Ishida M, Akagi H, Shimamoto K, Shinozaki H (1990) A potent metabotropic glutamate receptor agonist: electrophysiological actions of a configurationally restricted glutamate analogue in the rat spinal cord and Xenopus oocytes. Brain Res 537:311-314.

Ishida M, Saitoh T, Shimamoto K, Ohfune Y, Shinozaki H (1993a) A novel metabotropic glutamate receptor agonist: marked depression of monosynaptic excitation in the newborn rat isolated spinal cord. Br J Pharmacol 109:1 169-1177.

Ishida M, Saitoh T, Shinozaki H (1993b) A new metabotropic glutamate receptor agonist: developmental change of its sensitivity to receptors in the newborn rat spinal cord. Neurosci Lett 160:156-158.

Izumi Y, Clifford DB, Zorumski CF (1991) 2-Amino-3-phosphonopropionate blocks the induction and maintenance of long-term potentiation in hippocampal slices. Neurosci Lett 122:187-191.

Jane DE, Jones PLS, Pook PC-K, Salt TE, Sunter DC, Watkins JC (1993) Stereospecific antagonism by $(+)-\alpha$-methyl-4-carboxyphenylglycine (MCPG) of $(1 S, 3 R)$-ACPD-induced effects in neonatal rat motoneurones and rat thalamic neurones. Neuropharmacology 32: 725-727.

Kauer JA, Malenka RC, Nicoll RA (1988) A persistent postsynaptic modification mediates long-term potentiation in the hippocampus. Neuron 1:911-917.

Kitamura Y, Miyazaki A, Yamanake Y, Nomura Y (1993) Stimulatory effects of protein kinase $\mathrm{C}$ and calmodulin kinase II on $\mathrm{N}$-methyl-Daspartate receptor/channels in the postsynaptic density of rat brain. J Neurochem 61:100-109.

Klancnik JM, Phillips AG (1991) Modulation of synaptic plasticity in the dentate gyrus of the rat by electrical stimulation of the median raphe nucleus. Brain Res 557:236-240.

Lester RAJ, Jahr CE (1990) Quisqualate receptor-mediated depression of calcium currents in hippocampal neurons. Neuron 4:741-749.

Liu Y-B, Disterhoft JF, Slater NT (1993) Activation of metabotropic glutamate receptors induced long-term depression of GABAergic inhibition in hippocampus. J Neurophysiol 69:1000-1004.

Lonart G, Alagarsamy S, Johnson KS (1993) ( $R, S)$ - $\alpha$-amino-3-hydroxy-5-methylisoxazole-4-propionic acid (AMPA) receptors mediate a calcium-dependent inhibition of the metabotropic glutamate receptor-stimulated formation of inositol 1,4,5-trisphosphate. J Neurochem 60:1739-1745.

Lovinger DM (1991) Trans-1-aminocyclopentane-1,3-dicarboxylic acid $(t$-ACPD) decreases synaptic excitation in rat striatal slice through presynaptic action. Neurosci Lett 129:17-21.

Lovinger DM (1993) Metabotropic glutamate autoreceptor: mechanism of action and modulation by protein kinase C. Funct Neurol [Suppl] 8:32-33.

Lovinger DM, Wong KL, Murakami K, Routtenberg A (1987) Protein kinase $\mathrm{C}$ inhibitors eliminate hippocampal long-term potentiation. Brain Res 436:177-183.

Lovinger DM, Tyler E, Merritt AW (1992) Properties of a glutamate autoreceptor in rat striatum. Soc Neurosci Abstr 18:1366.

Lowry OII, Rosebrough NJ, Farr AL, Randall RJ (1951) Protein measurement with the Folin phenol reagent. J Biol Chem 193:265275.

Lynch G, Baudry M (1983) The biochemistry of memory: a new and specific hypothesis. Science 224:1057-1063.

Malenka RC (1991) Postsynaptic factors control the duration of synaptic enhancement in area CAl of the hippocampus. Neuron 6:5360

Malenka RC, Kauer JA, Perkel DJ, Kelly PT, Nicoll RA, Waxham MN (1989) An essential role for post-synaptic calmodulin and protein kinase activity in long-term potentiation. Nature 340:554-557.

Malinow R, Schulmann H, Tsien RW (1989) Inhibition of postsynaptic PKC or CAMKII blocks induction but not expression of LTP. Science 245:862-866

Manzoni OJJ, Finiels-Marlier F, Sassetti I, Bockaert J, le Peuch C, Sladeczek FAJ (1990) The glutamate receptor of the Qp-type activates protein kinase $\mathrm{C}$ and is regulated by protein kinase $\mathrm{C}$. Neurosci Lett 109:146-151.

Markram H, Segal M (1992) Activation of protein kinase C suppresses responses to NMDA in rat CA1 hippocampal neurones. J Physiol (Lond) 457:491-501.

Masu M, Tanabe Y, Tsuchida K, Shigemoto R, Nakanishi S (1991) Sequence and expression of a metabotropic glutamate receptor. $\mathrm{Na}-$ ture 349:760-765.

Matthies H, Behnisch T, Kase H, Matthies HJ, Reymann KG (1991) Differential effects of protein kinase inhibitors on pre-established longterm potentiation in rat hippocampal neurons in vitro. Neurosci Lett 121:259-262.

McGuiness N, Anwyl R, Rowan M (1991a) T-ACPD enhances longterm potentiation in the hippocampus. Eur J Pharmacol 197:231232.

McGuiness N, Anwyl R, Rowan M (1991b) The effects of trans-ACPD on long-term potentiation in the hippocampus. Neuroreport 2:688690.

McNaughton BL, Douglas RM, Goddard GV (1978) Synaptic enhancement in fascia dentata: cooperativity among co-active afferents. Brain Res 157:277-293.

Miles R, Poncer J-C (1993) Metabotropic glutamate receptors mediate a post-tetanic excitation of guinea-pig hippocampal inhibitory neurones. J Physiol (Lond) 463:461-473.

Monaghan DT, Bridges RJ, Cotman CW (1989) The excitatory amino acid receptors: their classes, pharmacology and distinct properties in the function of the central nervous system. Annu Rev Pharmacol Toxicol 29:365-402.

Morris RGM, Andersen E, Lynch G, Baudry M (1986) Selective impairment of learning and blockade of long-term potentiation by $N$-methyl-D-aspartate receptor antagonist AP5. Nature 319:774-776.

Muller D, Joly M, Lynch G (1989) Contributions of quisqualate and NMDA receptors to the induction and expression of LTP. Science 242:1694-1697.

Nakagawa Y, Saito K, Ishihara T, Ishida M, Shinozaki H (1990) $(2 S, 3 S, 4 S)$ - $\alpha$-(carboxycyclopropyl)glycine is a novel agonist of metabotropic glutamate receptors. Eur J Pharmacol 184:205-206. 
Nakanishi S (1992) Molecular diversity of glutamate receptors and implications for brain function. Science 258:597-603.

Nicoletti F, Iadarola MJ, Wroblewski JT, Costa E (1986) Excitatory amino acid recognition sites coupled with inositol phospholipid metabolism: developmental changes in interaction with $\alpha 1$-adrenoceptors. Proc Natl Acad Sci USA 83:1931-1935.

Nicoll RA, Malenka RC, Kauer JA (1990) Functional comparison of neurotransmitter receptor subtypes in mammalian central nervous system. Physiol Rev 70:513-565.

Ohishi H, Shigemoto R, Nakanishi S, Mizuno N (1993a) Distribution of messenger RNA for a metabotropic glutamate receptor, mGluR2, in the central nervous system of the rat. Neuroscience 53:1009-1018.

Ohishi H, Shigemoto R, Nakanishi S, Mizuno N (1993b) Distribution of mRNA for a metabotropic glutamate receptor, mGluR3, in the rat brain: an in situ hybridization study. J Comp Neurol 335:252-266.

Otani S, Ben-Ari Y (1991) Metabotropic receptor-mediated long-tcrm potentiation in rat hippocampal slices. Eur J Pharmacol 205:325326.

Otani S, Ben-Ari Y, Roisin-Lallemand MP (1993) Metabotropic receptor stimulation coupled to weak tetanus leads to long-term potentiation and rapid elevation of cytosolic protein kinase $\mathrm{C}$ activity. Brain Res 613:1-9.

Palmer E, Monaghan DT, Cotman CW (1989) Trans-ACPD, a selective agonist of the phosphoinositide-coupled excitatory amino acid receptor. Eur J Pharmacol 166:585-587.

Perkel DJ, Nicoll RA (1993) Evidence for all-or-none regulation of neurotransmitter release: implications for long-term potentiation. $\mathbf{J}$ Physiol (Lond) 471:481-500.

Pook PC-K, Sunter DC, Udvarhelyi PM, Watkins JC (1992) Evidence for presynaptic depression of monosynaptic cxcitation in neonatal rat motoneurones by $(1 S, 3 S)$ - and $(1 S, 3 R)$-ACPD. Exp Physiol 77:529532.

Porter RHP, Roberts PJ, Jane DE, Watkins JC (1992) (S)-homoquisqualate: a potent agonist at the glutamate metabotropic receptor. Br J Pharmacol 106:509-510.

Racine RJ, Milgram NW, Hafner S (1983) Long-term potentiation phenomena in the rat limbic forebrain. Brain Res 260:217-231.

Radpour S, Thomson AM (1992) Synaptic enhancement induced by NMDA and $Q_{p}$ receptors and presynaptic activity. Neurosci Lett 138: 119-122.

Rainnie DG, Shinnick-Gallagher P (1992) Trans-ACPD and L-APB presynaptically inhibit excitatory glutamatergic transmission in the basolateral amygdala. Neurosci Lett 139:87-91.

Reymann KG (1993) Mcchanism underlying synaptic long-term potentiation in the hippocampus: focus on postsynaptic glutamate receptors and protein kinases. Funct Neurol [Suppl] 5:7-31.

Reymann KG, Matthies H (1989) 2-Amino-4-phosphonobutyrate selectively eliminates late phases of long-term potentiation in the rat hippocampus. Neurosci Lett 98:166-171.

Reymann KG, Broedemann R, Kase H, Matthies H (1988) Inhibitors of calmodulin and protein kinase $\mathrm{C}$ block different phases of hippocampal long-term potentiation. Brain Res 461:388-392.

Reymann KG, Davies SN, Matthies H, Kase H, Collingridge GL (1990) Activation of a K-252b-sensitive protein kinase is necessary for a post-synaptic phase of long-term potentiation in area CAl of rat hippocampus. Eur J Neurosci 2:481-486.

Riedel G, Reymann K (1993) An antagonist of the metabotropic glutamate receptor prevents LTP in the dentate gyrus of frecly moving rats. Neuropharmacology 32:929-931.

Roberts PJ, Kemp MC, Porter RHP, Pook PCK, Jane DE, Jones A, Jones PLStJ, Sunter DC, Wharton B, Birse EF, Udvarheyi PM, Watkins JC (1993) Phenylglycine derivatives: novel tools for the pharmacological investigation of mGluRs. Funct Neurol [Suppl] 8:47.

Sahara Y, Westbrook GL (1991) Trans-ACPD blocks high threshold calcium currents on cultured hippocampal neurons. Soc Neurosci Abstr 17:1168.
Salt TE, Eaton SA (1991) Excitatory actions of the metabotropic excitatory amino acid receptor agonist, Trans-(1)-1-amino-cyclopentane-1,3-dicarboxylate ( $t$-ACPD) on rat thalamic neurones in vivo. Eur J Neurosci 3:1104

Sanchez-Prieto J, Herrero I, Vazquez E, Miras-Portugal MT (1993) Facilitation of exocytosis by metabotropic receptors in glutamatergic nerve terminals. Funct Neurol Suppl 8:48-49.

Schoepp DD, Conn PJ (1993) Metabotropic glutamate receptors in brain function and pathology. Trends Neurosci 14:13-20.

Schoepp DD, Bockaert J, Sladeczek F (1990a) Pharmacological and functional characteristics of metabotropic excitatory amino acid receptors. Trends Pharmacol Sci 11:508-511.

Schoepp DD, Johnson BG, Smith ECR, McQuaid LA (1990b) Stereoselectivity and mode of inhibition of phosphoinositide-coupled excitatory amino acid receptors by 2-amino-3-phosphonopropionic acid. Mol Pharmacol 38:222-228.

Schoepp DD, Johnson BG, Monn JA (1992) Inhibition of cyclic AMP formation by a selective metabotropic glutamate receptor agonist. J Neurochem 58:1184-1186.

Sergueeva OA, Fedorov NB, Reymann KG (1993) An antagonist of glutamate metabotropic receptors, $(R S)$ - $\alpha$-methy-4-carboxyphenylglycine, prevents the LTP-related increase in postsynaptic AMPA sensitivity in hippocampal slices. Neuropharmacology 32:933-935.

Shinozaki H, Ishida M (1992) A metabotropic L-glutamate receptor agonist: pharmacological difference between rat central neurones and crayfish neuromuscular junction. Comp Biochem Physiol 103C:1317.

Sladeczek F, Pin JP, Recacens M, Bockaert J, Weiss S (1985) Glutamate stimulates inositol phosphate formation in striatal neurons. Nature 317:717-719.

Stratton KR, Worley PF, Baraban JM (1989) Excitation of hippocampal neurons by stimulation of glutamate $Q_{p}$ receptors. Eur J Pharmacol 173:235-237.

Stratton KR, Worley PF, Baraban JM (1990) Pharmacological characterization of phosphoinositide-linked glutamate receptor excitation of hippocampal neurons. Eur J Pharmacol 186:357-361.

Sugiyama H, Ito I, Hirono C (1987) A new type of glutamate receptor linked to inositol phospholipid metabolism. Nature 325:531-533.

Sugiyama H, Ito I, Watanabe M (1989) Glutamate receptor subtypes may be classified into two major categories: a study on Xenopus oocytes injected with rat brain mRNA. Neuron 3:129-132.

Tanabe Y, Masu M, Ishii T, Shigemoto R, Nakanishi S (1992) A family of metabotropic glutamate receptors. Neuron 8:169-179.

Trommer BL, Colley PA, Pasternak JF, Kennelly JJ, Slater NT (1993) A developmental switch occurs in the long-term effects of metabotropic glutamate receptor activation in rat hippocampus. Soc Neurosci Abstr 19:1326.

Tsubokawa H, Robinson HPC, Takenawa T, Kawai N (1993) Block of long-term potentiation by intracellular application of anti-phosphoinositol-4,5-bisphosphate antibody in hippocampal pyramidal neurons. Neuroscience 55:643-651.

Weiler IJ, Greenough WT (1993) Metabotropic glutamate receptors trigger postsynaptic protein synthesis. Proc Natl Acad Sci USA 90: $7168-7171$.

Weisskopf MG, Zalutsky RA, Nicoll RA (1993) The opioid peptide dynorphin mediates heterosynaptic depression of hippocampal mossy fiber synapses and modulates long-term potentiation. Nature 362: $423-427$

Wigström H, Gustaffson B (1986) Postsynaptic control of hippocampal long-term potentiation. J Physiol (Paris) 81:228-236.

Winder DG, Conn PJ (1992) Activation of metabotropic glutamate receptors in the hippocampus increases cyclic AMP accumulation. J Neurochem 59:375-378.

Zalutsky RA, Nicoll RA (1990) Comparison of two forms of longterm potentiation in single hippocampal neurons. Science 248:16191624. 